\title{
ANALISIS PERBANDINGAN KARTU KREDIT KONVENSIONAL DAN KARTU KREDIT SYARIAH DITINJAU DARI PERSPEKTIF TUJUAN PENGGUNAAN
}

\section{COMPARISON OF THE CONVENTIONAL CREDIT CARD AND THE SHARIAH CREDIT CARD IN THE REVIEW OF THE USE PERSPECTIVE}

\author{
Syifa1a; Sofian Muhlisin²; Sahlan Hasbi ${ }^{3}$ \\ 1aProgram Studi Perbankan Syariah Fakultas Ekonomi Islam Universitas Djuanda, Jl. Tol \\ Ciawi No. 1 Bogor Kode Pos 16720, E-mail: Syifa@unida.ac.id \\ 2Program Studi Perbankan Syariah Fakultas Ekonomi Islam Universitas Djuanda, Jl. Tol \\ Ciawi No. 1 Bogor Kode Pos 16720 \\ ${ }^{3}$ Program Studi Perbankan Syariah Fakultas Ekonomi Islam Universitas Djuanda, Jl. Tol \\ Ciawi No. 1 Bogor Kode Pos 16720
}

\begin{abstract}
This Study aims to find out the comparison between conventional credit card users and sharia credit cards so that they can determine the factors that influence interest in ownership and purpose of use between conventional and sharia credit cards. This research method uses descriptive qualitative method of analysis with field research techniques. The results of the study show that there are differences in interest in conventional credit card ownership is more to the needs of sharia shopping and credit card transactions more to the wishes in accordance with sharia. The purpose of the use of conventional credit card user respondents with a percentage of 60 percent is used for primary, ssecondary, and tertiary needs while the purpose of using 40 percent of credit card users is used for primary, secondary and tertiary needs.
\end{abstract}

Keywords: Conventional credit cards, Islamic cedit cards, Ownership factors, Purpose of use.

\begin{abstract}
ABSTRAK
Penelitian ini bertujuan untuk mengetahui perbandingan antara pengguna kartu kredit konvensional dan kartu kredit syariah sehingga dapat diketahui faktor-faktor yang mempengaruhi minat kepemilikan dan tujuan penggunaan antara kartu kredit konvensional dan syariah. Metode penelitian ini menggunakan metode kualitatif analisis deskriptif dengan teknik penelitian field research. Hasil penelitian menunjukan bahwa terdapat perbedaan faktor minat kepemilikan kartu kredit konvensional adalah lebih kepada kebutuhan transaksi pembelanjaan dan kartu kredit syariah lebih kepada keinginan yang sesuai dengan syariah. Adapun tujuan penggunaan responden pengguna kartu kredit konvensional dengan jumlah persentase yaitu 60 persen digunakan untuk kebutuhan primer, sekunder, dan tersier sedangkan tujuan penggunaan responden pengguna kartu kredit syariah dengan persentase 40 persen digunakan untuk kebutuhan primer, sekunder, dan tersier.
\end{abstract}

Kata kunci: Kartu kredit konvensional, Kartu kredit syariah, Faktor kepemilikan, Tujuan penggunaan. 
Syifa. 2019. Analisis Perbandingan Kartu Kredit Konvensional dan Kartu Kredit Syariah Ditinjau dari Perspektif Tujuan PenggunaanImplementasi Asset Protection Rationale Pada Pembiayaan Korporasi di Bank Syariah. Nisbah: Jurnal Perbankan Syariah 5 (1): 55-65.

\section{PENDAHULUAN}

Perkembangan bisnis kartu plastik sudah semakin pesat baik di tingkat nasional maupun tingkat dunia hal itu dikarenakan bisnis kartu plastik yang berperan dalam kegiatan Bisnis dengan berbagai faktor yang ditawarkan berupa keamanan, kenyamanan dan kemudahan. Salah satu yang termasuk jenis kartu plastik adalah kartu kredit dimana Kartu Kredit termasuk kredit yang terdapat faktor kemudahan utnuk digunakan serta memiliki syarat yang sederhana. Kartu kredit di Indonesia pertama kali di perkenalkan tahun 1980 oleh Bank Duta, pada masa itu kartu kredit yang dipasarkan masih bersifat konvensional dan pengguanaanya hanya digunakan oleh orang-orang yang berpergian keluar negeri (Farhan;Irsad, 2012:22). Penggunaan credit card sekarang ini digunakan oleh masyarakat sebagai gaya hidup yang modern, alternatif pendapatan bahkan dapat menutupi kekurangan penghasilan setiap bulannya. Kemudahan kartu kredit yang semakin dirasakan oleh card holder untuk melakukan transaksi yang membutuhkan yang banyak tanpa membawanya secara langsung. Penggunaan kartu kredit menjadi semakin luas antara konven dan syariah. Perbedaan antara keduanya yaitu bagi kartu kredit dengan basis syariah memiliki sejumlah dasar hukum selain pada UU Perbankan dan aturan perbankan syariah, serta Fatwa DPS dan MUI Lembaga industri jasa keuangan baik indutri jasa keuangan syariah maupun industri jasa keuangan konvensional maka industri jasa haruslah memiliki strategi untuk mencapai tujuan seperti mempertahankan loyalitas nasabah nya serta mampu meningkatkan aktifitas menjadi lebih baik lagi sehingga dapat meningkatkan jumlah transaksi yang menjadi suatu tujuan utama bagi lembaga keuangan sebagai penerbit kartu kredit, agar para pemegang kartu senantiasa mengaplikasikan kartu kredit yang baru menjadi hal yang sering digunakan untuk transaksi sehingga mampu memiliki kemampuan untuk dapat menarik minat nasabahnya tentu dengan melakukan promosi yang menarik sehingga masyarakat dapat menemukan produk kartu kredit untuk tujuan penggunaan baik tujuan penggunaan konsumtif atau pun tujuan penggunaan produktif sehingga masyarakat mempunyai pilihan untuk menjadi pengguna dari kedua kartu kredit tersebut khususnya umat muslim yang mencari produk sesuai dengan prinsip islam.

\section{MATERI DAN METODE}

\section{Pengertian Kartu Kredit.}

Kartu Kredit merupakan transaksi pembayaran jual beli atas suatu pembelian barang dan jasa di mana pembayarannya dilakukan secara mencicil dengan sejumlah minimum tertentusehingga kartu ini disebut sebagai alat pengganti uang tunai, transaksi tersebut dapat ditemukan pada tempat-tempat (merchant) yang berhubungan kerja dengan pihak penerbit kartu (Ariyani, 2014:117).

\section{Persamaan Kartu Kredit}

Persamaan credit card dan syariah card Pertama, memiliki fungsi yang sama, yaitu sebagai alat pembayaran tagihan rumah tangga Kedua, biaya-biaya seperti 
annual fee / iuran tahunan yaitu iuran pembayaran setiap tahun oleh card holder. Iuran tersebut akan ditagih setiap tahun melalui lembar penagihan, late charge/ biaya keterlambatan yaitu ta'widh dan denda. Ketiga, pihak yang terlibat yakni pihak issuer bank, card holder, dan merchant.

\section{Perbedaan Kartu Kredit}

Credit card dan shariah card terdapat Perbedaan dilihat dari segi perhitungan biaya bunga sedangkan kartu kredit syariah tidak dikenakan bunga melainkan dikenakan beberapa ketentuan yang pertama yaitu Member Ship , kedua kartu kredit ini dilihat dari segi perhitungan biaya bunga (Muhammad, 2002:36) sedangkan pada syariah tanpa adanya bunga melainkan dikenakan beberapa ketentuan yang pertama yaitu Member Ship Fee (Iuran Keanggotaan) ujrah atas jasa penggunaan fasilitas kartu yang besarnya ditentukan oleh bank. Kartu kredit syariah juga terdapat batasan yang ditetapkan menurut MUI kartu kredit syariah, ketentuan batasan syariah tersebut diantaranya tidak menimbulkan riba, tidak untuk transaksi yang haram serta tidak israf atau berlebihan.

\section{Proses Kerja Kartu Kredit}

Proses Kerja Kartu kredit pertama Nasabah (Customer) mengajukan permohonan membuka kartu kredit sesuai syarat. Kedua, lembaga penerbit kartu menerbitkan kartu apabila disetujui setelah melalui penelitian terhadap credibilitas dan kapasitas calon nasabah. Ketiga, Nasabah dapat melakukan transaksi pembelian dengan merchant. Keempat, pihak pedagang (Merchant) akan menagih ke bank sesuai dengan bukti transaksi. Kelima, bank akan membayar nya sesuai dengan perjanjian yang disepakati.Keenam, bank akan menagih pada nasabah pemegang kartu berdasarkan bukti pembelian sesuai dengan perjanjian. Ketujuh, pemegang kartu membayar kembali pada bank (Pujiono, 2005:67).

\section{Lembaga Keuangan Penerbit Kartu Kredit}

Kartu kredit disediakan oleh lembaga perbankan yaitu bank konvensional dan bank syariah sebagai penyedia mekanisme transaksi pembayaran yang efisien dan tanggung jawab (Zaharman, 2016:249).

Bank konvensional yakni bank yang memberikan service atau jasa lalu lintas pembayaran secara konvensional (Iqbal, 2012:338) sedangkan shariah bank yakni memberikan jasa lalu lintas pembayaran secara syariah. (Andespa, 2016:44). Perkembangan kartu kredit syariah atau shariah card di indonesia hingga tahun 2017 dari 34 BUS dan UUS, terdapat dua kartu kredit syariah satu diterbitkan oleh BUS yakni Hasanah card oleh BNI Syariah dan satu lagi diterbitkan oleh UUS yakni Kartu Pembiayaan yang diterbitkannya oleh UUS Bank CIMB Niaga.

Kartu-kartu kredit syariah di indonesia memberikan alternatif yang baik penggunaanya yang berkompetisi dalam hal pelayanan dengan basis syariah khususnya penggunaan bagi umat muslim agar digunakan sebaik mungkin untuk meminimaisir sistem bunga dalam upaya konsep mualamah yang berkeadilan (Nurhayati, 2015:27). Bank Islam dalam transaksi penggunaan kartu kredit dapat melakukan improvisasi dengan meningkaitkan strategi pemberian limit lebih besar pada pengguna kartu kredit. tujuannya adalah untuk menghindari risiko gagal bayar (Wahyudi, Dewi,dkk, 2013:120).

\section{Jenis Akad yang digunakan pada Kartu Kredit syariah}

Kartu Kredit Syariah dan Jenis Akad yang digunakan Perbankan syariah sebagai lembaga dengan aransemen profit dan loos sharing di mana dalam semua aktivitasnya harus menaati 
hukum syariah, tentu didalamnya terdapat akad-akad setiap transaksi perbankan syariah yang harus memenuhi ketentuan berdasarkan prinsip islam, pihak-pihak terikat oleh ketentuan hukum islam yang berupa hak-hak dan pemenuhan kewajiban-kewajiban yang harus diwujudkan (wadiah \& Trihatana, 2015:102).

Akad harus memenuhi rukun akad dan syaratnya yang pertama rukun akad diantaranya yaitu adanya penjual dan pembeli, objek, dan akad /ijab Qabul, dimana sighat atau ijab Qabul hasrus sesuai dengan akad, jelas pengertiannya (Shiddieqy, 2001:29). Kedua adanya syarat akad diantaranya yaitu suatu barang maupun jasa yang tentunya halal, harga yang jelas, tempat yang jelas, barang merupakan kepemilikan penuh (Antonio, 2001:30).

Kegiatan muamalah yang dilakukan lembaga syariah tentunya harus memahami ilmu akad fiqih muamalah dimana termasuk teknik yang tepat untuk mendesain suatu akad, dimana transaks syariah pada bank syariah tentu penerapan sebuah transaksi harus sesuai dengan aturan syariah (Karim A.,2004:94). Transaksi syariah mempunyai akad-akad yang terkandung di dalamnya yakni Ijarah, qard, kafalah dan hawalah (Yusuf, 2011:259)

\section{Teori Konsumtif dalam Islam}

Teori konsumtif dalam Islam lahir karena adanya suatu kebutuhan dan keinginan. Kebutuhan menurut Imam Al Ghazali diartikan sebagai kebutuhan manusia dalam rangka untuk mempertahankan kelangsungan hidupnya (Nasution, 2010; 68). Penegasan pembatasan antara kebutuhan dan keinginan diperlukan dalam islam, agar konsumsi menjadi lebih terarah dan terkendali. Kebutuhan konsumen muslim dituntun oleh rasionalitas ajaran Islam agar memperoleh maslahah secara optimal, oleh karena itu dalam upaya pencapaian maslahah secara optimal, konsumsi seorang muslim perlu memperhatikan prinsip-prinsip konsumsi Islami, batasan konsumsi Islami, dan etika konsumsi islami (Elvira, 2016:180)

Tujuan yang paling utama dalam konsumsit bagi muslim khususnya yaitu untuk meningkatkan kekuatan dalam ketaatan ibadah maka dengan adanya niat beribadah akan menjadikan aktivitas konsumsi tersebut bernilai ibadah dan tentunya akan mendapat pahala dan ridha Allah SWT, sedangkan bagi konvensional yang di nilai sebagai tujuan yang besar dalam ekonomi di mana kebahagaiannya diukur dengan kemampuan nerkonsumsi maka untuk menjelaskan tentang membandingkan konsumsi yang lebih baik menurut ekonomi islam dan kapitalis karya ilmiah ini juga menyinggung masalah kosumsi bagi masyarakat, kemudian pola kosumsi masyarakat muslim dengan pola konsumsi masyarakat kapitalis (Almizan, 2016:15). Penggunaan credit card dengan adanya kebutuhan dan keinginan.

Kebutuhan adalah sesuatu yang dirasakan ketidak beradaannya untuk memenuhi kepuasan secara dasar, seperti makanan, pakaian, tempat tempat berlindung atau rasa aman, hak milik sedangkan keinginan hasrat untuk pemuas kebutuhan sesuai dengan kondisi lingkungan mereka (Hasan, 2010:13). Maqashid syariah terdapat maslahah menurut Imam Al-Ghazali dimana mashlahah dari sesaui dengan: : Agama/ Ad-din, Hidup atau jiwa/Nafs, Keluarga atau keturunan /Nasl, Harta atau kekayaan / Maal, Intelek atau akal/Aql, Imam Al-Ghazali berfokus pada kebaikan dunia ini dan akhirat merupakan tujuan utamanya" (Ilyas, 2016:167).Perilaku Konsumsi yang utama mmemperhatikan aspek yang tergolong kebutuhan primer (Dharuriyat), kemudian sekunder 
(Hajiyyat) dan Tersier (Tahsiniyat) sesuai dengan semangat Al Maqashid Asy-Syariah. (Pujiono, 2006:200).

\section{Jenis dan Objek Penelitian}

Penelitian yang digunakan adalah jenis penelitian kualitatif, penelitian kualitatif bergantung pada pengamatan manusia dalam keadannya sendiri dan berhubungan dengan orang-orang tersebut (Hayati, 2012:346). Data kualitatif dinyatakan dalam bentuk kata, kalimat, gambar, dan tidak dapat dinyatakan dengan angka-angka. Penelitian kualitatif juga bertujuan untuk mendapatkan pemahaman yang sifatnya umum terhadap kenyataan sosial dari perspektif partisipan (Subandi, 2011:176).

Objek penelitian disini membandingkan kartu kredit yang ditinjau dari tujuan penggunaan, maka objek penelitian ini adalah masyarakat pengguna kartu kredit baik pengguna kartu kredit baik konvensional maupun syariah. Penelitian ini tidak perlu mempersoalkan jumlah sample secara kuantitatif untuk melakukan suatu penelitian, dalam hal ini penarikan sampel yang digunakan sebanyak 20 sample yakni 10 orang pengguna kartu kredit konvensional dan 10 orang pengguna kartu kredit syariah. Jenis data yang digunakan yakni primer dan sekunder.

Sumber data yang diperoleh melalui sumber data yang didapatkan secara ekstern yakni yang diperoleh dari luar instansi (Lembaga, Organisasi).

a. Data primer

Data yang diambil langsung dari sumbernya seperti kuesioner dan wawancara langsung ke narasumber (Misna, 2015:527). Data ini bersumber dari masyarakat yang mennggunakan credit card masyarakat pengguna kartu kredit syariah. b. Data Sekunder

Data sekunder yaitu data yang sudah tersusun dan biasanya berbentuk dokumen yang diambil secara tidak langsung dari narasumber (Wandansari, 2013:561). Data sekunder yakni didapatkan dari literatur kepustakaan seperti Jurnal, Buku, dan sumber lainnya yang berkaitan dengan jurnal penelitian ini, untuk mendapatkan landasan teoritis yang menyeluruh tentang produk suatu lembaga keuangan salah satunya kartu kredit baik itu kartu kredit konvensional maupun kartu kredit syariah.

Teknik atau cara pengumpulan data yang dibutuhkan denngan menggunakan beberapa teknik yaitu: Library Research (Studi Kepustakaan) Studi Kepustakaan yaitu adanya pengumpulan data dengan cara mempelajari bahan-bahan tertulis (Khatibah, 2011:38). Penelitian ini studi kepustakaan meliputi seperti buku, jurnal, serta artikel terkait. Field Research (Studi Lapangan) Studi Lapangan yakni pengumpulan suatu data dengan pengamatan langsung dengan melakukan wawancara kepada seorang informan atau seorang authoritas (seorang yang berwenang dalam suatu masalah) (Harahap, 2014:68).

Teknik pengumpulan data ini agar dapat mempermudah pengumpulan data ini, maka peneliti harus menggunakan instrumen pengumpulan data ini adalah:

a. Metode dokumentasi

Metode yang digunakan dengan mencari data seperti buku-buku dan jurnal ilmiah untuk memperoleh landasan teoritis yang menyeluruh serta anaisis tentang produk kartu kredit dokumen berupa gambar, analisis hasil wawancara yang berkaitan dengan pengguna kartu kredit (Setiawati, 2015:108).

b. Metode Studi Kepustakaan (Liberari Research)

Metode ini dan panduan studi 
dokumen, penulis membuat catatan panduan studi dokumen, paduan ini adalah pedoma untuk memperoleh dokumen, bahan literatur, arsip, maupun data tertentu yang terdokumentasi. Paduan ini berupa daftar rangkuman, daftar kebutuhan studi dokumen yang biasa dijadikan dasar bagi penulis dalam membuat dasar dalam menganalisa menganalisa permasalahan pada penelitian.

c. Metode Kuesioner

\begin{tabular}{lcr}
\multicolumn{1}{c}{ Metode } & kuesioner & yaitu \\
pengiriman & kuesioner & yang \\
dilakukan & pemberian & lembar
\end{tabular}
pertanyaan kepada responden yaitu analisis pengguna kartu kredit untuk mengumpulkan data primer. Metode wawancara, dalam melakukan wawancara yang merupakan alat rechecking atau bukti adanya informasi yang didapat sebelumnya.

d. Teknik Wawancara

Panduan wawancara yang di pergunakan sebagai pedoman dalam menjalankan wawancara yang dibuat secara sederhana dan mudah untuk dimengerti baik oleh pewawancara maupun informan, teknik ini adalahwawancara mendalam (InDepth Interview) dengan cara tanya jawab yang secara bertatap muka antara pewawancara dengan yang diwawancarai (Rahmat, 2009:6), Dalam melakukan wawancara mendalam adalah memperhatikan intonasi uara, kejelasan, kecepatan dalam berbiacara, pertanyaan, serta kontak mata. Pengolahan data, setelah proses pengumpulan data telah selesai, data yang dikumpulkan selanjutnya diolah melalui tahapantahapan sebagai berikut:

Pertama, Persiapan data yang dilakukan untuk mengecek kelengkapan dan kebenaran atas data yang didapatkan dari hasil jawaban wawancara, dan studi dokumen. Kedua, Iktisar data adalah merubah dari rekaman atau catatan tulisan tangan selama melakukan wawancara, maupun studi dokumen agar dapat mempermudah untuk mengklasifikasi data maupun menganalisa data dari transkip disarikan isi-isi pokok penting pandangan informan terkait permasalahan dan pertanyaan yang disampaikan terkait dengan penelitian. Ketiga, Pembuatan koding setelah data di transkip maka perlu pembacaan ulang atas isi transkip atau catatan maupun tulisan tangan yang telah dirubah secara teliti, data kemudian pada bagian tertentu dianggap penting akan dicatat dan diambil kata kunci dimana kata kunci tersebut akan digunakan kode tertentu. Keempat, Klasifikasi setelah data diseleksi kemudian diklasifikasikan berdasarkan kategori-kategori yang disusun sedemikian rupa sehingga akan memudahkan untuk menjadi data yang layak dianalisis. Kelima, Tabulasi data yaitu setelah data diklasifikasi kemudian disusun dalam bentuk tabel ataupun grafik, sehingga akan mempermudah penulis dalam menganalisis.

\section{HASIL DAN PEMBAHASAN}

\section{Faktor-Faktor yang Mempengaruhi Minat Kepemilikan Credit Card dan Shariah Card}

Dari hasil penelitian melalui wawancara kepada 10 responden konvensional dan 10 responden syariah, dari hasil wawancara terseut terdapat jawaban faktor minat kepemilikan yang konvensional dan faktor minat kepemilikan yang syariah, yang pertama akan dijelaskan dari hasil penelitian pada responden konvensional mengenai jawaban faktor adanya minat suatu 
kepemilikan credit card yang konvensional.

Klasifikasi hasil penelitian terhadap responden syariah dapat diperhitungkan bahwa terdapat 1 responden yang menjawab karena faktor perhitungan yaitu perhitungan biaya juga yang lebih murah, terdapat 5 reponden yang menjawab faktor keinginan yakni keinginan yang sesuai dengan syariah, terdapat 6 responden yang menjawab karena faktor internal yakni sebagai karyawan bank syariah, dan terdapat 2 responden yang menjawab karena faktor kemudahan. Salah satu faktor minat tersebut merupakan salah satu faktor pengetahuan sosial serta pendidikan yang tidak hanya proses transfer ilmu pengetahuan namun pendidikan juga membiasakan peserta didik untuk berpikir, bersikap dan bertindak menurut kaidah-kaidah ilmiah sesuai dengan tingkat pendidikannya (Handayani \& Kurnia, 2015:65).

Hasil penelitian tersebut dapat diambil kesimpulannya bahwa faktor minat kepemilikan shariah card di pengaruhi oleh faktor perhitungan biaya, faktor keinginan yang sesuai dengan syariah, faktor internal yakni sebagai karyawan bank syariah, faktor kemudahan akses. Kedua klasifikasi tersebut tentu dapat ditarik suatu kesimpulan yakni faktor-faktor adalah sebagai berikut:

Tabel 1.

Faktor-faktor yang mempengaruhi minat kepemilikan kartu kredit

\begin{tabular}{|c|l|l|}
\hline No. & $\begin{array}{l}\text { Faktor minat } \\
\text { kepemilikan } \\
\text { kartu kredit } \\
\text { konvensional }\end{array}$ & $\begin{array}{l}\text { Faktor minat } \\
\text { kepemilikan kartu } \\
\text { kredit syariah }\end{array}$ \\
\hline 1 & Faktor promosi & $\begin{array}{l}\text { Faktor keinginan } \\
\text { sesuai syariah }\end{array}$ \\
\hline 2 & $\begin{array}{l}\text { Faktor } \\
\text { kebutuhan } \\
\text { transaksi }\end{array}$ & $\begin{array}{l}\text { Faktor kebutuhan } \\
\text { transaksi }\end{array}$ \\
\hline 3 & Faktor & Faktr kemudahan \\
\hline
\end{tabular}

\begin{tabular}{|c|l|l|}
\hline & $\begin{array}{l}\text { kemudahan } \\
\text { akses }\end{array}$ & akses \\
\hline 4 & $\begin{array}{l}\text { Faktor dari } \\
\text { bank } \\
\text { (Bonus kartu } \\
\text { kredit) }\end{array}$ & $\begin{array}{l}\text { Faktor internal } \\
\text { (karyawan pada } \\
\text { bank syariah) }\end{array}$ \\
\hline 5 & $\begin{array}{l}\text { Faktor } \\
\text { Perhitungan } \\
\text { (Diskon, } \\
\text { program } \\
\text { cicilan, jumlah } \\
\text { limit) }\end{array}$ & $\begin{array}{l}\text { Faktor } \\
\text { perhitungan } \\
\text { (Lebih murah, } \\
\text { tidak ada bunga) }\end{array}$ \\
\hline
\end{tabular}

Sumber: Data diolah, 2018

Faktor tersebut dapat dilihat persamaannya konvensional dan syariah yakni faktor kebutuhan transaksi dan kemudahan akses, sedangkan perbedaan nya yaitu pada faktor konvensional adalah faktor promosi, faktor bonus mendapatkan kartu kredit dari bank, dan faktor perhitungan dari diskon, jumlah limit, dan program cicilan, sedangkan pada faktor minat kepemilikan shariah card yakni faktor keinginan yang syariah karena didalamnya terdapat batasan penggunaannya sehingga harus berdasarkan prinsip syariah yaitu tidak dibolehkan untuk hal yang haram, israf atau berlebihan, dan hal yang tidak bermanfaat, kemudian karena faktor internal yakni sebagai karyawan pada bank syariah yang telah mengeluarkan produk shariah card salah satunya adalah PT.BNI Syariah, dan juga adanya faktor perhitungan yakni biaya lebih murah karena tidak adanya bunga berbunga Hasil penelitian ini terlihat juga pada hasil penelian terdahulu menurut (Lestari,2017:147).

\section{Tujuan Penggunaan Kartu Kredit}

Tujuan Penggunaan Kartu Kredit dilihat dari beberapa Jenis kebutuhan yaitu kebutuhan primer sekunder,maupun tersier, dari 10 responden syariah masing-masing memilih jenis penggunaan kebutuhan yang berbeda sehingga bagian-bagian yang terdapat pada pemilihan jenis 
kebutuhan hampir semua jenis penggunaan terisi oleh responden konvensional dari 3 jenis kebutuhan yakni kebutuhan primer, sekunder, dan tersier dari jenis kebutuhan tersebut masing-masing terdapat 4 tujuan penggunaan sehingga terdapat 12 tujuan penggunaan dan masing-masing responden syariah memiliki perbedaan tujuan penggunaan dari 10 responden syariah atau shariah card dari hasil penelitian yang telah dilakukan hanya terdapat 6 tujuan penggunaan yang di pilih dan juga digunakan digunakan oleh responden syariah yakni tujuan penggunaan untuk kebutuhan makanan, penggunaan untuk kebutuhan pakaian, penggunaan untuk bepergian yakni membayar tiket transportasi yakni pesawat dan grab, penggunaan untuk kebutuhan pariwisata yakni bayar hotel, penggunaan untuk kebutuhan alat elektronik yakni laptop, dan penggunaan untuk kebutuhan accessories yakni sepatu, tujuan-tujuan penggunaan tersebut lebih dipilih dan digunakan responden syariah, dan terdapat 6 tujuan penggunaan yang tidak dipilih dan tidak digunakan oleh responden syariah yaitu tujuan penggunaan untuk kebutuhan ibadah, penggunaan untuk kebutuhan perbaikan tempat tinggal/rumah, penggunaan untuk kebutuhan fashion, penggunaan untuk kebutuhan kesehatan, penggunaan untuk kebutuhan membeli alat transportasi, penggunaan untuk kebutuhan perhiasan, tujuan-tujuan penggunaan tersebut yang tidak dipilih dan juga digunakan oleh responden $t$ syariah.

Hasil penelitian yang terdapat pada tujuan penggunaan dari card holder dapat diketahui bahwa terdapat perbedaan antara tujuan penggunaan yang dilakukan oleh pengguna credit card dan shariah card yakni tujuan penggunaan pada responden konvensional lebih banyak menggunakan untuk kebutuhan konsumtif dibandingan tujuan penggunaan yang dilakukan oleh responden syariah, pada card holder yang konvensional banyak digunakan untuk ketiga kebutuhan yakni tersier, sekunder bahkan primer yang lebih dominan untuk keperluan membeli makanan, pakaian, tiket transportasi, booking hotel, dan kebutuhan accessories, sedangkan tujuan penggunaan oleh responden syariah lebih sedikit digunakan dibanding dengan konvensional, dimana responden syariah hanya lebih banyak digunakan untuk kebutuhan sekunder dan kebutuhan tersier yaitu lebih dominan kepada tujuan penggunaan untuk tiket transportasi dan elektronik.

Terlihat hasil dari penjelasan penelitian pada bagian tujuan penggunaan diatas yakni tujuan penggunaan bagi responden konvensional dan tujuan penggunaan bagi responden syariah yang hasilnya terdapat perbedaan antara keduanya yaitu pada responden konvensional memilih dari 12 tujuan penggunaan terdapat 10 tujuan penggunaan yang dipilih atau digunakan sebagai tujuan yan penggunaanya menggunakan kartu kredit dan hanya terdapat 2 tujuan penggunaan yang tidak dipilih atau tidak digunakan oleh responden card holder, sedangkan pada responden syariah memilih dari 12 tujuan penggunaan hanya terdapat 6 tujuan penggunaan yang dipilih atau digunakan sebagai tujuan yang penggunaannya menggunakan shariah card serta terdapat 6 tujuan penggunaan pula yang tidak dipilih/tidak digunakan oleh responden shariah card, hal tersebut dapat diketahui bahwa tujuan penggunaan bagi kartu kredit yang konvensional lebih konsumtif dibanding dengan shariah card yang memiliki batasan penggunaan sehingga dengan adanya batasan penggunaan nasabah card holder secara perlahan dapat menjaga penggunaannya agar tetap 
dalam batas wajar.

Nasabah card holder yang syariah dan konvensional tetap harus memperhatikan jumlah limit yang dimilikinya agar tetap bisa digunakan sesuai dengan tujuan penggunaan sesuai dengan kebutuhan dan keinginan. Penggunaan kartu kredit diatas dapat di jelaskan menurut teori Imam Al-Ghazali salah satunya yang menjelaskan bagaimana teori konsumsi dalam islam, hal tersebut dapat diketahui bahwa hasil penelitian diatas yang penggunaanya lebih kepada tujuan konsumtif dapat dijelaskan pula kedalam teori konsumsi dalam islam yaitu menurut imam AlGhazali, dimana teori penggunaan kebutuhan yang terdapat pada kartu kredit juga harus memperhatikan lima unsur pemahaman konsumsi dalam Islam, yaitu: Menjalankan perintah Allah SWT yaitu menjalankan perintah Allah dalam konteks berkonsumsi adalah melalui konsumsi pada produk-produk yang halal saja, baik halal zatnya dan cara mendapatkannya karena konsumsi produk yang halal akan mendatangkan maslahah dan berkah yang tidak didapat dari konsumsi produk yang haram, hal ini telihat bahwa shariah card tentu tidak ada bunga berbunga dan tujuan penggunaanya tidak dapat digunakan secarra bebas melainkan untuk pembelian dan digunakan untuk konteks yang halal.

Menjauhi larangan Allah SWT , Allah SWT telah menjelaskan hal-hal apa saja yang diharamkan bagi seorang muslim untuk dikonsumsi, selain pelarangan konsumsi produk produk yang haram, pelarang untuk berkonsumsi secara berlebihan juga dilarang dalam Islam, hal tersebut dapat dilihat pada tujuan penggunaan memiliki batasan-batasan syariah sehingga card holder dapat menjaga penggunaannya untuk tidak digunakan dalam hal-hal terlarang dan tidak memiliki manfaat seperti dilarang untuk digunakan karaokean.

Israf atau berlebih-lebihan dalam islam didefinisikan sebagai suatu aktivitas konsumsi yang melebihi kebutuhan diri seseorang, untuk menghindari israf, Imam Al Ghazali mengemukakan bahwa membuat skala prioritas konsumsi sebagai upaya untuk mengurangi israf dalam berkonsumsi bagi seorang muslim, hal ini terlihat pada tujuan penggunaan bagi kartu kredit yang konvensional lebih banyak digunakan untuk berbagai macam kebutuhan.

Menafkahkan sebagian harta miliknya di jalan Allah SWT, yakni dalam ekonomi islam maka unsur pendapatan masyarakat tentunya dialokasikan kedalam beberapa pengeluaran yaitu untuk aktifitas konsumsi, pengeluaran kedalam bentuk menabung dan dari pendapatan tersebut sebagiannya dikurangkan ke dalam bentuk infak dan shadaqah, hal ini tentunya sesuai dengan sabda Rasulullah SAW(Sarwono, 2009:36).

\section{KESIMPULAN DAN IMPLIKASI}

Berdasarkan pengelolaan data dan hasil analisis data yang sesuai dengan permasalahan penelitian dan tujuan penelitian, maka kesimpulannya adalah sebagai berikut:

1. Faktor adanya minat suatu kepemilikan credit card yang konvensional yakni faktor promosi, faktor kebutuhan transaksi, faktor kemudahan akses, faktor internal yaitu bonus dari bank, faktor perhitungan yaitu program cicilan dan jumlah limit. Adapun tujuan penggunaan kartu kredit konvensional semua jenis kebutuhan digunakannya mulai dari kebutuhan yang primer, kebutuhan sekunder, serta kebutuhan tersier hanya saja terdapat penggunaan yang tidak sama sekali digunakan yaitu dari jenis kebutuhan 
primer seperti kebutuhan ibadah dan kebutuhan peralatan atau renovasi tempat tinggal tidak terdapat pengguna credit card yang menggunakannya.

2. Faktor adanya minat suatu kepemilikan shariah card yakni faktor keinginan sesuai syariah, faktor kebutuhan transaksi, faktor kemudahan akses, faktor internal yaitu sebagai karyawan pada bank syariah, faktor perhitungan yaitu lebih murah dan tidak adanya sistem bunga. Adapun tujuan penggunaan kartu kredit syariah semua terdapat penggunaan dari jenis kebutuhan yang primer, kebutuhan sekunder, serta kebutuhan tersier akan tetapi banyak penggunaan yang tidak digunakan oleh card holder yang syariah seperti penggunaan untuk kebutuhan ibadah, renovasi tempat tinggal, fashion, kesehatan,transportasi dan kebutuhan perhiasan, penggunaan-penggunaan tersebut tidak digunakan oleh card holder syariah.

3. Perbandingan kartu kredit konvensional dan kartu kredit syariah memiliki perbedaan diantara keduanya yakni dari segi faktor minat kepemilikan dimana masyarakat ingin menggunakan kartu kredit syariah dipengaruhi oleh faktor promosi seperti hadiah atau promo di hari-hari besar, faktor perhitungan seperti adanya diskon, faktor bonus kartu kredit dari bank untuk nasabah penghimpun dana, sedangkan pada minat kepemilikan shariah card dipengaruhi oleh tidak adanya sistem bunga dan keinginan produk syariah.

4. Perbandingan tujuan penggunaan kartu kredit sesuai dengan hasil penelitian bahwa tujuan penggunaan bagi kartu kredit yang konvensional lebih konsumtif dibanding dengan pengguna kartu kredit syariah karena memiliki batasan penggunaan sehingga dengan adanya batasan penggunaan nasabah card holder secara perlahan dapat menjaga penggunaannya agar tetap dalam batas wajar hal tersebut dijelaskan teori konsumsi menurut imam AlGhazali penggunaan dengan pola konsumsi harus memperhatikan lima unsur pemahaman konsumsi dalam Islam yaitu menjalan perintah Alah SWT, menjauhi larang Allah SWT, serta tidak berlebih-lebihan atau israf.

\section{DAFTAR PUSTAKA}

Almizan. (2016). Konsumsi menurut Ekonomi Islam dan Kapitalis. $A l$ Masraf (Jurnal Lembaga Keuangan dan Perbankan) Volume 1, Nomor 1, Januari-Juni, 15.

Andespa, R. (2016). . Strategi Industri Perbankan di Sumatra Barat: Pemilihan Segmentasi Pasar untuk menciptakan Pelayanan yang memuaskan. Maqdis: Kajian Ekonomi Islam, Volume 1, Nomor 1, Januari-Juni, 44-49.

Aryani, R. M. (2014). Peranan Kartu Plastik (Plastic Card) Dalam Bisnis. Jurnal Ekonomi Volume 2, Nomor 2, Januari-April, 117.

Elvira, R. (2016). Pengaruh Persepsi Konsumen Muslim terhadap Maslahah terhadap Keputusan Konsumsi terbatas hanya pada Komoditas Halal. Manhaj, Volume 2, Nomor 2, Mei-Agustus, 180.

Handayani, R. P. (2013). Analisis Persepsi Masyarakat Kota Bogor terhadap Wakaf Tunai. Bogor: Fakultas Ekonomi dan Bsinis Syariah Universitas Djuanda.

Harahap, N. (2014). Penelitian Kepustakaan. Jurnal Iqra, Volume 8, Nomor 1, Mei, 68.

Ilyas, R. (2016). Etika Konsumsi dan Kesejahteraan dalam perspektif Ekonomi Islam. At-Tawassuth, Volume 1, Nomor 1, 167-169. 
Iqbal, M. (2012). Analisis Perbandingan Kinerja Keuangan Perbankan Syariah dengan Perbankan Konvensional. Jurnal Episteme, Volume 7, Nomor 2, Desember, 338.

Khatibah. (2011). Penelitian Kepustakaan. Jurnal Iqra, Volume 5, Nomor 1, Mei, 38.

Lestari, B. A., Suharjo, B., \& Muflikhati, I. (2017). Minat Kepemilikan Kartu Kredit (Studi Kasus Kota Bogor). Jurnal: Aplikasi Bisnis dan Manajemen, Volume 3, Nomor 1, Januari, 144.

Lubis, A. F., \& Lubis, I. (2012). Analisis Perilaku Masyarakat Muslim Terhadap Penggunaan Kartu Kredit di Kota Medan. Ekonomi dan Keuangan, Volume 1, Nomor 1, Desember, 23.

Nasution, B. (2013). Sistem Koordinasi antara Bank Indonesia dan Otoritas Jasa Keuangan dalam Pengawasan Bank setelah Lahirnya UndangUndang Nomor 21 Tahun 2011 Tentang Otoritas Jasa Keuangan. Transparency Jurnal Hukum Ekonomi, Volume 1, Nomor 2, Februari-Mei, 5.

Nurhayati. (2008). Studi Perbandingan Metode Sampling antara Simple Random dengan Stratified Random. Jurnal Basis Data, ICT Research Center UNAS, Volume 3, Nomor 1, Mei, 39.

Pujiono, A. (2005). Islamic: Credit Card (Suatu Kajian terhadap Sistem Pembayaran Islam Kontemporer). Dinamika Pembangunan, Volume 2, Nomor 1, Juli, 67.

Pujiono, A. (2006). Teori Konsumsi Islam. Dinamika Pembangunan, Volume 3, Nomor 2, Desember, 198-200.

Rahmat, P. S. (2009). Penelitian Kualitatif. Jurnal Equilibrium, Volume 5, Nomor 9, Januari-Juni, 69.
Sarwono. (2009). Analisis Perilaku Konsumen Dalam Perspektif Ekonomi Islam. Jurnal Inovasi pertanian, Volume 8, Nomor 1, , 46.

Setiawati, M. G. (2015). Analisis Sistem Informasi Aplikasi Online Kartu Kredit Menggunakan Metode SERQUAL (Studi Kasus ANZ Bank). Jurnal Telekomunikasi dan Komputer, Volume 6, Nomor 2, ISSN 2085-4811, September, 108.

Subandi. (2011). Deskriptif Kualitatif sebagai satu metode dalam pertunjukan. Jurnal Harmonia, Volume 11, Nomor 2, Desember, 176.

wadiah, S., \& Trihatana, R. (2015). Analisis Penerapan Good Corporate Governance pada Bank Umum Syariah berdasarkan peraturan Bank Indonesia No.11/33/PBI/2009. Jurnal Nisbah, Volume 1, Nomor 2, Desember, 102.

Yusuf, A. (2011). Perbandingan Kartu Kredit dan Kartu Kredit Berbasis Syariah Di Indonesia. Jurnal AlIqtishad, Volume III, Nomor 2, Juli, 255-262.

Zaharman. (2016). Analisis Perbedaan Kinerja Keuangan Perbankan Syariah dengan Perbankan Konvensional . Ilmiah Ekonomia dan Bisnis EISSN:2442-9813 ISSN: 1829-9822, Volume 14, Nomor 2, September, 249. 
Jurnal Nisbah Vol. 5 No. 1 Tahun $2018 \mid 66$ 